\title{
KEMAMPUAN INTELLIGENCE QUOTIENT (IQ) MAHASISWA FAKULTAS KEDOKTERAN UNIVERSITAS SAM RATULANGI
}

\author{
${ }^{1}$ Rinto Mangiwa \\ ${ }^{2}$ H.I.S. Wungouw \\ ${ }^{2}$ D.H.C. Pangemanan
${ }^{1}$ Kandidat Skrispi Fakultas Kedokteran Universitas Sam Ratulangi Manado
${ }^{2}$ Bagian Fisiologi Fakultas Kedokteran Universitas Sam Ratulangi Manado
Email:rintomangiwa@gmail.com

\begin{abstract}
In education, intelligence utilized to determine the extent of achievement of learning that can be achieved by an individual. Intelligence factors that result in the difference between someone with another intelligence is innate, environmental, physical condition, social background and socioeconomic. Research purposes to describe the ability of qoutient intelligence ( IQ ). Descriptive survey study was conducted using the method of cross -sectional study to measure the ability of student's Intelligence Quotient ( IQ ) of the Faculty of Medicine, University of Sam Ratulangi. Number of respondents 100 people, consisting of 50 men and 50 women. Based on the results obtained IQ `measurement capability results in 11 respondents ( $22 \%$ ) of male respondents have the ability IQ with Superior category, the other 11 people ( $22 \%$ ) categorized as Above Average, the remaining 28 men ( $56 \%$ ) had Average IQ ability . Women on the ability of IQ respondents only 1 ( 2 $\%$ ) are categorized as Superior, 9 people ( $18 \%$ ) categorized as Above Average, and the remaining 40 ( $80 \%$ ) were classified as having the ability IQ category average.
\end{abstract}

Keywords: Intelligence Capabilities Qoutien, Student’s.

Abstrak: Dalam bidang pendidikan, intelegensi dimanfaatkan untuk mengetahui sejauh mana prestasi belajar yang dapat dicapai oleh suatu individu. Faktor-faktor intelegensi yang mengakibatkan terjadinya perbedaan antara intelegensi seseorang dengan yang lain yaitu pembawaan, lingkungan hidup, kondisi fisik, latar belakang sosial ekomoni dan pendidikan. Tujuan penelitian untuk mengetahui gambaran kemampuan intelligence qoutient (IQ). Penelitian dilakukan secara survey deskriptif dengan mengunakan metode cross sectional study untuk mengukur kemampuan Intelligence Quotient (IQ) mahasiswa Fakultas Kedokteran Universitas Sam Ratulangi. Jumlah responden 100 orang, terdiri dari Laki-laki 50 orang dan Perempuan 50 orang. Berdasarkan hasil penelitian pengukuran kemampuan IQ diperoleh hasil pada responden 11 orang (22\%) responden laki-laki memiliki kemampuan IQ dengan kategori Superior, sebanyak 11 orang (22\%) masuk kategori diatas rata-rata, sisanya 28 orang (56\%) memiliki kemampuan IQ rata-rata. Pada responden perempuan pada kemampuan IQ hanya 1 orang (2\%) yang masuk kategori Superior, 9 orang (18\%) masuk kategori diatas rata-rata, dan sisanya 40 orang $(80 \%)$ memiliki kemampuan IQ yang tergolong kategori ratarata.

Kata kunci: Kemampuan Intelligence Qoutient, mahasiswa.

Dalam bidang pendidikan, intelegensi dimanfaatkan untuk mengetahui sejauh mana prestasi belajar yang dapat dicapai oleh suatu individu. Individu dalam menyelesaikan masalah apakah cepat atau lambat, faktor yang turut menentukan adalah faktor intelegensi dari individu yang bersangkutan. Intelegensi dan keberhasilan dalam pendidikan adalah dua hal yang saling berkaitan. Anak yang memiliki 
itelegensi yang tinggi biasanya akan memiliki prestasiyang membanggakan di kelasnya, dan dengan prestesi yang dimilikinya ia akan lebih mudah meraih keberhasilan. $^{1}$

Tes intelegensi, dapat digunakan untuk seleksi masuk sekolah maupun perguruaan tinggi. Kapasitas intelektual selalu menjadi salah satu pertimbangan seseorang diterima atau tidak. karena diyakini dapat berpengaruh terhadap kemampuan berpikir logis, kemampuan menganalisa, dan kemampuan untuk memecahkan masalah dalam pekerjaannya. ${ }^{2,3}$

\section{METODE PENELITIAN}

Penelitian ini menggunakan survey deskriptif dengan menggunakan metode cross sectional study. Penelitian dilaksanakan di Fakultas Kedokteran Universitas Sam Ratulangi di Kleak, Manado. Waktu penelitian dilakukan pada bulan desember 2013. Dengan Populasi penelitian adalah mahasiswa Fakultas Kedokteran UNSRAT Program Studi Kedokteran Umum angkatan 2013 berjumlah 258 orang. Pemilihan sampel menggunakan metode purposive sampling. Dengan jumlah minimal 100 orang yang memenuhi kriteria inklusi sebagai berikut: Mahasisawa aktif Fakultas Kedokteran UNSRAT Angkatan 2013. Bersedia menjadi responden penelitian. Defenisi operasional Intelligence Quotient (IQ) adalah pendekatan penilaian kemampuan kognitif individu.

\section{HASIL}

Dari hasil penelitian yang didapatkan, gambaran kemampuan IQ mahasiswa kedokteran Universitas Sam Ratulangi. dimana sampel penelitian berjumlah 100 orang, dengan 50 mahasiswa dan 50 mahasiswi.

Berdasarkan Data pada Tabel 1, diperlihatkan jumlah responden laki-laki yang terbanyak diperoleh pada kelompok umur 18 tahun, yaitu sebanyak 24 orang (48\%). Pada kelompok umur 15 tahun yaitu sebanyak 1 orng (2\%), pada umur 16 tahun yaitu sebanyak 2 orang (4\%), pada umur 17 tahun yaitu sebanyak 17 orang (34\%), pada umur 19 tahun yaitu sebanyak 5 orang (10\%), dan pada umur 20 tahun yaitu sebanyak 1 orang (2\%).

Tabel 1. Gambaran Responden Berdasarkan Umur dan Jenis Kelamin

\begin{tabular}{lcccc}
\multirow{2}{*}{$\begin{array}{l}\text { Umur } \\
\text { (Tahun) }\end{array}$} & \multicolumn{2}{c}{ Laki-laki } & \multicolumn{2}{c}{ Perempuan } \\
\cline { 2 - 5 } & $\mathrm{n}$ & $\%$ & $\mathrm{n}$ & $\%$ \\
\hline 15 & 1 & 2 & 0 & 0 \\
16 & 2 & 4 & 3 & 6 \\
17 & 17 & 34 & 21 & 42 \\
18 & 24 & 48 & 25 & 50 \\
19 & 5 & 10 & 1 & 2 \\
20 & 1 & 2 & 0 & 0 \\
\hline Total & 50 & 100 & 50 & 100 \\
\hline
\end{tabular}

Tabel 2. Gambaran Responden Berdasarkan Asal Sekolah

\begin{tabular}{lcc} 
Asal Sekolah & n & Persentase \\
\hline Sekolah & 61 & $61 \%$ \\
$\begin{array}{l}\text { Negeri } \\
\text { Sekolah }\end{array}$ & 39 & $39 \%$ \\
$\begin{array}{l}\text { Swasta } \\
\text { Total }\end{array}$ & 100 & $100 \%$ \\
\hline
\end{tabular}

Berdasarkan asal sekolah menengah atas responden, diketahui sebanyak 61 responden (61\%) berasal dari sekolah negeri dan sebanyak 39 responden (39\%) berasal dari sekolah swasta.

Tabel 3. Gambaran Responden Berdasarkan Cara Masuk Fakultas Kedokteran UNSRAT

\begin{tabular}{lcc}
\hline Cara masuk FK & n & Persentase \\
\hline SBMPTN & 55 & $55 \%$ \\
undangan & & \\
SBMPTN tertulis & 22 & $22 \%$ \\
Tumou Tou & 23 & $23 \%$ \\
Jalur Khusus & 0 & $0 \%$ \\
\hline Total & 100 & $100 \%$ \\
\hline
\end{tabular}


Mangiwa, Wungouw, Pangemanan; Kemampuan Intelligence Quotient Mahasiswa...

Berdasarkan cara masuk FK, 55 responden (55\%) masuk melalui cara seleksi bersama masuk perguruan tinggi negeri (SBMPTN) undangan, 22 responden (22\%) masuk melalui SBMPTN tertulis, 23 responden (23\%) masuk melalui seleksi total (Tumou Tou), dan tidak ada responden yang masuk melalui jalur khusus.

Tabel 4. Gambaran Responden Berdasarkan Keinginan Masuk Fakultas Kedokteran UNSRAT

\begin{tabular}{llc}
\hline Keinginan masuk FK & n & Persentase \\
\hline Sendiri & 90 & $90 \%$ \\
Orang tua & 10 & $10 \%$ \\
Lainnya & 0 & $0 \%$ \\
\hline Total & 100 & $100 \%$ \\
\hline
\end{tabular}

Berdasarkan keinginan untuk masuk FK, 90 responden (90\%) mengaku masuk FK menurut keinginannya sendiri, 10 responden (10\%) mengaku masuk FK oleh karena dorongan orang tua, dan tidak ada responden (0\%) masuk FK oleh karena ada alasan lainnya.

Tabel 5. Gambaran Responden Berdasarkan Status Tempat Tingal

\begin{tabular}{lcc}
\hline Tempat Tingal & n & Persentase \\
\hline Rumah sendiri & 49 & $49 \%$ \\
Rumah keluarga & 10 & $10 \%$ \\
Kost & 39 & $39 \%$ \\
Lainnya & 2 & $2 \%$ \\
\hline Total & 100 & $100 \%$ \\
\hline
\end{tabular}

Berdasarkan menurut tempat tinggal, 49 responden (49\%) tinggal di rumah orang tua, 10 responden (10\%) tinggal di rumah keluarga, 39 responden (39\%) tinggal di kost, dan 2 responden (2\%) tinggal di tempat lainnya.
Tabel 6. Gambaran Kemampuan IQ pada Responden Laki-laki

\begin{tabular}{|c|c|c|}
\hline \multicolumn{3}{|c|}{ Kategori Intelligence Qoutien (IQ) } \\
\hline IQ & $\mathrm{n}$ & $\%$ \\
\hline Genius $\geq 170$ & 0 & 0 \\
\hline Sangat Superior 140-169 & 0 & 0 \\
\hline Superior 120-139 & 11 & 22 \\
\hline Diatas Rata-rata 110-119 & 11 & 22 \\
\hline Rata-rata 90-190 & 28 & 56 \\
\hline Dibawah Rata-rata $\leq 80$ & 0 & 0 \\
\hline Total & 100 & \\
\hline
\end{tabular}

Pada Tabel 6, didapatkan gambaran kemampuan IQ dari responden Laki-laki, diperoleh hasil IQ hanya didapat 11 orang yang termasuk kategori Superior (22\%). Sebanyak 11 orang yang termasuk ketegori Diatas Rata-rata (22\%). Pada kategori Ratarata terdapat 28 orang (56\%), Sedangkan pada kategori Genius, Sangat Superior dan Dibawah Rata-rata tidak ditemukan.

Tabel 7. Gambaran Kemampuan IQ pada Responden Perempuan

\begin{tabular}{llc}
\hline Kategori Intelligence Qoutien (IQ) \\
\hline IQ & $\mathrm{n}$ & $\%$ \\
Genius $>170$ & 0 & 0 \\
Sangat Superior 140-169 & 0 & 0 \\
Superior 120-139 & 1 & 2 \\
Diatas Rata-rata 110-119 & 9 & 18 \\
Rata-rata 90-190 & 40 & 80 \\
Dibawah Rata-rata $<80$ & 0 & 0 \\
\hline Total & 50 & 100 \\
\hline
\end{tabular}

Pada Tabel 7, didapatkan gambaran kemampuan IQ dari responden Perempuan, diperoleh hasil IQ hanya didapat 1 orang yang termasuk kategori Superior (2\%). Sebanyak 9 orang yang termasuk ketegori Diatas Rata-rata (18\%). Pada kategori Ratarata terdapat 40 orang (80\%), Sedangkan pada kategori Genius, Sangat superior dan Dibawah Rata-rata tidak ditemukan.

\section{BAHASAN}

Berdasarkan penelitian yang dilakukan kepada mahasiswa kedokteran Universitas 
Sam Ratulangi, maka di dapatkan gambaran hasil mengenai kemampuan IQ mahasiswa dan mahasiswi kedokteran Universitas Sam Ratulangi dengan responden sebanyak 100 orang yang terdiri dari laki-laki 50 orang dan perempuan 50 orang, tidak terdapat responden yang memiliki kemampuan IQ dengan Kategori Genius. Pada kemampuan IQ, didapatkan 68 orang responden memiliki kemampuan IQ dalam kategori Rata-rata, 20 orang responden masuk kategori Diatas Rata-rata, hanya 11 orang responden lakilaki dan 1 orang responden perempuan yang memiliki kemampuan IQ dalam kategori Superior.

Berdasarkan hasil penelitian pada kemampuan IQ, diperoleh hasil 11 orang (22\%) responden laki-laki memiliki kemampuan IQ dengan kategori Superior, yang lainnya 11 orang (22\%) masuk kategori Diatas Rata-rata, sisanya 28 orang (56\%) memiliki kemampuan IQ Rata-rata. Pada responden Perempuan pada kemampuan IQ hanya 1 orang (2\%) yang masuk kategori Superior, 9 orang (18\%) masuk kategori Diatas Rata-rata, dan sisanya 40 orang (80\%) memiliki kemampuan IQ yang tergolong kategori Rata-rata.

Hasil penelitian yang diperoleh memperlihatkan bahwa kemampuan IQ dari mahasiswa dan mahasiswi responden penelitian di Fakultas Kedokteran Universitas Sam Ratulangi tidak ada yang masuk katergori Genius, Sangat superior dan Dibawah Rata-rata, ini mungkin disebabkan oleh beberapa faktor-faktor yang mempengaruhi intelegensi yaitu pembawaan atau keturunan, latar belakang sosial ekonomi, lingkungan hidup, kondisi fisik, pendidikan dan motivasi.sehingga akhirnya sebagian besar responden memiliki kemampuan IQ Rata-rata. Inilah pentingnya faktorfaktor yang mempengaruhi intelegensi, untuk menghasilkan kemampuan IQ yang baik.

Bayley (2005) dalam penelitiannya ada beberapa faktor yang mempengaruhi kemampuan intelektual individu dengan individu yang lain, yaitu:

\section{Pembawaan atau keturunan}

Studi kolesrasi nilai-nilai tes Inteligensi diantara anak dan orang tua, atau dengan kakek-neneknya, menunjukan adanya pengaruh faktor keturunan terhadap tingkat kemampuan mental seseorang sampai pada tingkat tertentu.

2. Latar belakang sosial ekonomi Pendapatan keluarga, pekerjaan orang tua dan faktor-faktor sosial ekonomi lainya, bertoleransi positif dan cukup tinggi dengan taraf kecerdasan individu mulai usia 3 tahun sampai pada remaja.

3. Lingkungan, hidup Lingkungan yang kurang baik akan menghasilkan kemampuan intelektual yang kurang baik pula. Lingkungan yang di nilai paling buruk bagi perkembangan Intelegensi adalah panti-panti asuhan serta institusi lainnya, terutama bila anak ditempatkan disana sejak awal kehidupannya.

4. Kondisi fisik Keadaan gizi yang kurang baik, kesehatan yang buruk, perkembangan fisik yang lambat, menyebabkan tingkat kemampuan mental yang rendah.

5. Pendidikan, Tentu saja memberikan pengalaman intelektual yang lebih luas sehingga tingkat pendidikan terkait dengan tingkat intelektual akan memungkinkan orang beradaptasi dengan berbagai kondisi kehidupan.

6. Motivasi, pada setiap orang pada tingkat usia yang berbeda akan melahirkan motivasi yang berbeda pula. Misalnya anak-anak lebih termotivasi untuk mendapatkan perhatian dari orang tua atau orang dewasa, sedangkan remaja akan termotivasi untuk meraih prestasi di sekolah. ${ }^{4}$

Khadijah (2009) mengemukakan, inteligensi seseorang diyakini sangat berpengaruh pada keberhasilan belajar yang dicapainya. Berdasarkan hasil penelitian, prestasi belajar biasanya berkorelasisearah dengan tingkat inteligensi. Artinya, semakin tinggi tingkat inteligensi seseorang, maka semakin tinggi prestasi belajar yang dicapainya. ${ }^{5,6}$ 
Mangiwa, Wungouw, Pangemanan; Kemampuan Intelligence Quotient Mahasiswa...

Anak yang memiliki inteligensi abnormal, baik sangat tinggi (Genius) maupun yang sangat rendah (Dibawah Ratarata) sama-sama menimbulkan masalah bila ditinjau dari dunia pendidikan. Pentingnya makna perbedaan individual, khususnya dalam hal inteligensi, membawa kesadaran dalam dunia pendidikan akan perlunya perlakuan khusus terhadap anak didik yang tergolong memiliki tingkat inteligensi tidak biasa. Anak yang memiliki inteligensi begitu rendah sehingga kemampuan belajarnya sangat terbatas memerlukan program khusus yang memungkinkan mereka belajar dengan beban kecepatan yang sesuai dengan keterbatasan mereka. Pada sisi lain, anak yang memiliki kemampuan Genius pun memerlukan program khusus yang memungkinkan mereka mengembangkan segenap potensi lebih yang mereka punyai sehingga dapat mencapai prestasi yang optimal dan tidak menimbulkan problem psikologis lain. ${ }^{7,8}$

\section{SIMPULAN}

Berdasarkan hasil penelitian 11 orang (22\%) responden laki-laki memiliki kemampuan IQ dengan kategori Superior, yang lainnya 11 orang (22\%) masuk kategori Diatas Rata-rata, sisanya 28 orang (56\%) memiliki kemampuan IQ Rata-rata.
Pada responden Perempuan pada kemampuan IQ hanya 1 orang (2\%) yang masuk kategori Superior, 9 orang (18\%) masuk kategori Diatas Rata-rata, dan sisanya 40 orang (80\%) memiliki kemampuan IQ yang tergolong kategori Rata-rata.

\section{DAFTAR PUSTAKA}

1. Arisandy, Desy. 2006. Psikodiagnostik IIIInteligensi (Diktat). Palembang: Bina Darma.

2. Amthauer, R. 1973. I-S-T 70: Intelligenz Struktur Test. Handanweisung fur die Durchfuhrung und Auswertung.4. Auflage. Gottingen: Hogrefe.

3. Anastasi A, Urbina S. 2006. Tes Psikologi. Terjemahan. Edisi Ketujuh. Jakarta: PT indeks.

4. Slameto, 2005, Belajar dan Faktor-Faktor yang mempengaruhinya, Bandung: Rinaksara.

5. Khadijah, Nyanyu. 2009. Psikologi Pendidikan. Palembang: Grafika Telindo Press.

6. Azwar, Saifuddin. 2004. Pengatar Psikologi Inteligensi. Yogyakarta: Pustaka pelajar.

7. Yusuf, Syamsu. 2006. Psikologi Perkembangan Anak dan Remaja. Bandung: PT Remaja Rosdakarya.

8. Gunadi, L. 2012. Hubungan Antara Intelegensi dan Motivasi Berprestasi Terhadap Prestasi Akademik, Jakarta. 